\title{
Emergence of Greenhouse Whitefly (Trialeurodes vaporariorum) Transmitted Criniviruses as Threats to Vegetable and Fruit Production in North America
}

William M. Wintermantel, Ph.D.

Research Plant Pathologist

USDA-ARS Crop Improvement and Protection Unit

Salinas, CA 93905

Email: wwintermantel@pw.ars.usda.gov

The greenhouse whitefly (GHWF) (Trialeurodes vaporariorum Westwood) has been a problem in greenhouses for many years, both as an insect pest capable of reducing plant productivity and longevity, as well as a virus vector (Fig. 1). Within the last ten years this whitefly pest has been emerging as a serious threat to vegetable and fruit production in the field as well. The GHWF has become a particular problem along the west coast of North America, where populations now reach levels capable of yield reduction through feeding damage alone in a number of crops (1). This region is rich in agriculture, producing the majority of vegetables and strawberries grown in the United States and in Mexico.

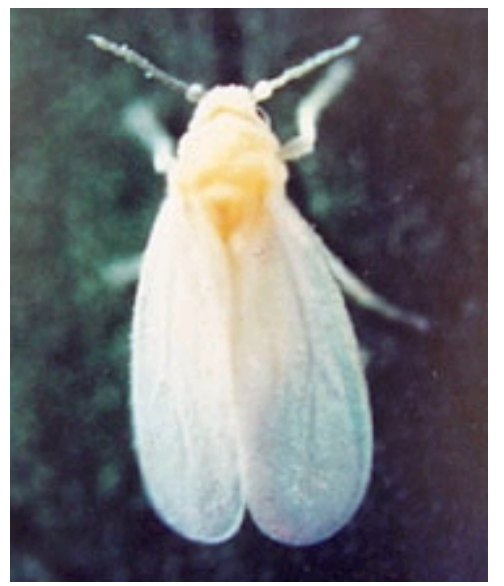

Fig. 1A. Mature greenhouse whitefly (Trialeurodes vaporariorum). Unless otherwise noted, all photos are courtesy of W. M. Wintermantel, USDA-ARS, Salinas, CA. 


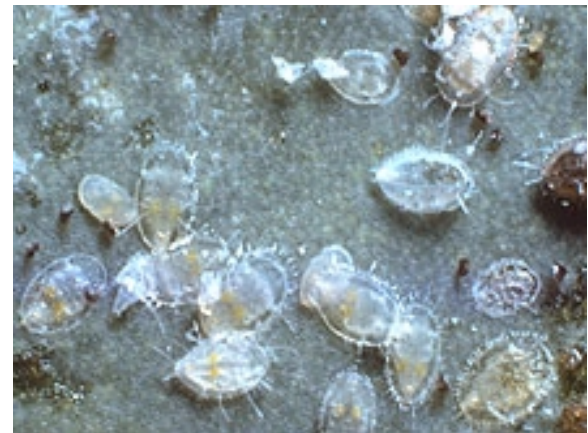

Fig. 1B. Greenhouse whitefly ( $T$. vaporariorum) nymphs (Photo courtesy of $\mathrm{T}$. Perring, University of California, Riverside, $\mathrm{CA})$.

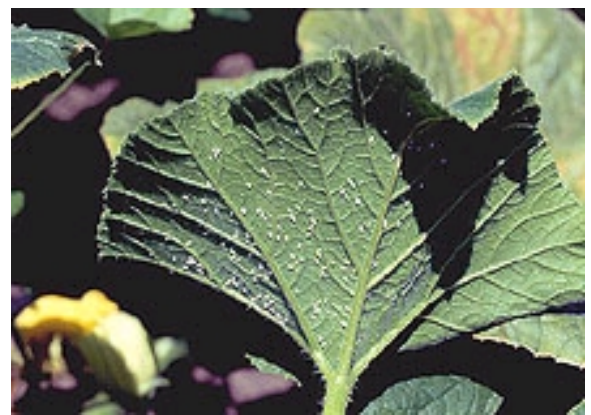

Fig. 1C. Greenhouse whitefly ( $T$. vaporariorum) on the lower surface of a pumpkin (Cucurbita maxima) leaf.

Climatic conditions along the west coast of North America, along with an abundance of crop and weed species suited for propagation of GHWF, have facilitated the recent explosion in summer populations of this insect pest. The GHWF thrives on numerous crops as well as weed species that occur in coastal regions, particularly on plants in the families Asteraceae, Cucurbitaceae, Malvaceae, and Solanaceae, although plant species in at least 14 families were shown to support feeding by GHWF nymphs ( $T$. Perring, personal communication). Specific crops affected by whitefly feeding and serving as GHWF propagative hosts include tomato (Lycopersicon esculentum Mill.), lettuce (Lactuca sativa L.), strawberry (Fragaria ananassa Duch.), cucumber (Cucumis sativus L.), squash (Cucurbita pepo L.) and pumpkin (Cucurbita pepo L./C. maxima Duch.), among others.

Although whiteflies themselves can cause significant crop damage, GHWF-vectored viruses can cause losses that are much more economically damaging than those resulting from vector feeding alone. The majority of known whitefly-transmitted viruses are transmitted by Bemisia tabaci (Gennadius) biotypes. The best known B. tabaci-transmitted viruses are those in the genus, Begomovirus (Geminiviridae), which contains $90 \%$ of the whitefly-transmitted viruses characterized to date (17). Many of these viruses cause serious damage to agricultural crops. Most are transmitted by the $B$ biotype of B. tabaci (also referred to as B. argentifolii Bellows and Perring). In addition to the begomoviruses, B. tabaci transmits a limited number of viruses in the genera Carlavirus, I pomovirus (Potyviridae), and Crinivirus (Closteroviridae). The only whitefly genus other than Bemisia identified as a virus vector is Trialeurodes. In contrast to the large numbers of viruses transmitted by Bemisia, only a handful of viruses have been found to be transmitted by Trialeurodes, all within the genus Crinivirus. The genus Crinivirus contains viruses transmitted by both Bemisia and Trialeurodes (33) (Table 1). 
Table 1. Whitefly transmission specificity of criniviruses

\begin{tabular}{|l|l|}
\hline Criniviruses (partial list) & Whitefly Vector* \\
\hline Abutilon yellows virus (AYV) & BW \\
\hline Beet pseudo yellows virus (BPYV) & GH \\
\hline Cucurbit yellow stunting disorder virus (CYSDV) & SL, SP \\
\hline Lettuce chlorosis virus (LCV) & SL \\
\hline Lettuce infectious yellows virus (LIYV) & SP \\
\hline Strawberry pallidosis associated virus (SPaV) & GH \\
\hline Sweet potato sunken vein virus (SPSVV) & SL \\
\hline Tomato chlorosis virus (ToCV) & SL, BW, SP, GH \\
\hline Tomato infectious chlorosis virus (TICV) & GH \\
\hline
\end{tabular}

* BW, Banded wing whitefly (T. abutilonea); GH, Greenhouse whitefly (T. vaporariorum); SL, Silverleaf whitefly (B. tabaci biotype B); SP, Sweet potato whitefly (B. tabaci biotype A).

Begomoviruses are transmitted in a persistent manner. During whitefly feeding begomoviruses are ingested by the vector and become circulative in the hemolymph of the insect vector prior to transmission. Viruses must pass through the gut wall to the hemolymph, and eventually to the salivary glands from which it can be transmitted to susceptible hosts. Once acquired, begomoviruses can be transmitted for extended periods ranging from weeks to the life of the insect (13). In contrast, criniviruses are transmitted in a semipersistent manner and do not become circulative in their whitefly vectors. They can be acquired by the whitefly vector after feeding for periods as short as an hour, however, efficiency of transmission increases with longer acquisition access feeding periods (the time the vector is allowed to feed on an infected source plant) up to 48 hours. Unlike begomoviruses, criniviruses can only be transmitted for a finite amount of time ranging from 1 to 9 days depending on the virus $(33,35)$. Most criniviruses are transmitted by a single whitefly species, however, at least one exception exists in which a virus can be transmitted by whiteflies of both Bemisia and Trialeurodes genera (34).

Criniviruses are an emerging genus worldwide, with numerous new species having been identified within the past several years $(2,4,7,8,25,29,34)$. Criniviruses often cause symptoms that are readily mistaken for physiological or nutritional disorders or pesticide phytotoxicity. These symptoms often include interveinal yellowing of leaves, an associated loss of photosynthetic capability, leaf brittleness, reduced plant vigor, yield reductions and early senescence, depending on the host plant affected. Symptoms are typically most apparent on middle to lower parts of plants, while new growth appears normal (Fig. 2). Criniviruses remain confined to cells associated with host plant phloem, and symptoms are thought to result from plugging of the phloem with large viral inclusion bodies, which probably interfere with normal vascular transport in infected plants (35). 


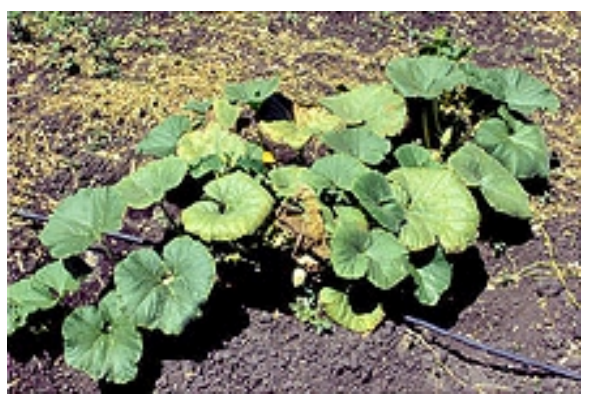

Fig. 2. BPYV infection on pumpkin (Cucurbita maxima), illustrating the typical pattern of crinivirus symptom development. Symptoms develop first on older leaves while new growth remains symptom free. Symptoms gradually progress outward over time.

Criniviruses have large bipartite RNA genomes encoding several open reading frames (ORFs). RNAl encodes functions involved in virus replication, while RNA2 encodes up to 7 ORFs involved in virion assembly, vector transmission and other functions, many of which remain to be determined (11). Virions are encapsidated into long flexuous rods averaging between 650 to $900 \mathrm{~nm}$ in length (Fig. 3).

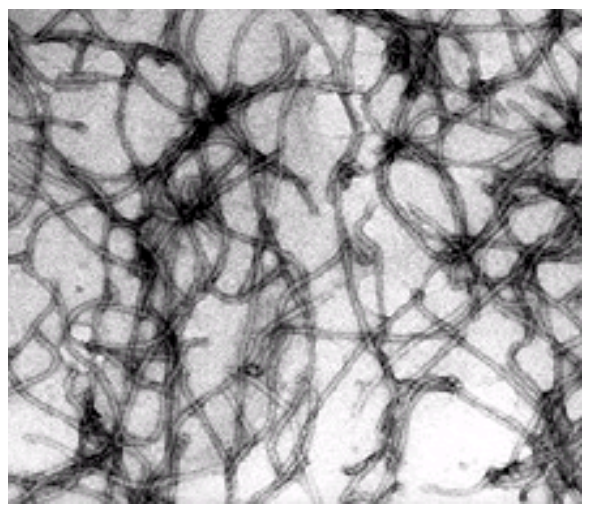

Fig. 3. Electron micrograph of TICV particles (80,000 $\times$ magnification). (Photo courtesy of H.- Y. Liu, USDA-ARS, Salinas, CA).

Four GHWF-transmitted crinivirus species have been identified to date, including Beet pseudo yellows virus (BPYV), Strawberry pallidosis associated virus (SPaV), Tomato chlorosis virus (ToCV) and Tomato infectious chlorosis virus (TICV). All four GHWF-transmitted criniviruses have exerted significant pressure on vegetable and fruit production in North America, Europe, and other parts of the world, affecting both greenhouse-grown crops as well as field crops. This article focuses primarily on BPYV, SPaV, and TICV, as these three criniviruses are transmitted exclusively by GHWF, and are currently responsible for economic damage to vegetable and fruit production. Although ToCV is transmitted by the GHWF and impacts tomato production, it is much more efficiently transmitted by $\mathrm{B}$. tabaci biotype $B$ than by GHWF (35), and its incidence is associated more closely with the presence of $\mathrm{B}$. tabaci in fields and greenhouses than with GHWF. The GHWF transmitted criniviruses have host ranges of varying size, ranging from quite narrow in the case of SPaV, to extremely broad in the case of BPYV (16). Although all GHWFtransmitted criniviruses infect weed species and wild relatives of cultivated crops, their primary agricultural impact occurs on three major groups of crops. TICV and ToCV exert their main economic impact on tomato production in both greenhouse and field settings 
(33). SPaV is a problem in strawberry (25), and BPYV with its extensive host range infects numerous cucurbit species $(6,30)$, as well as strawberry (24) and blackberry (26).

Disease problems in vegetable and fruit crops resulting from GHWF-transmitted criniviruses

TI CV and ToCV in Tomato. In the mid-1990s two new criniviruses emerged as threats to tomato production in North America. TICV and ToCV cause identical symptoms on tomato, including interveinal yellowing and thickening of leaves $(32,34)$ (Fig. 4). Although no obvious fruit symptoms occur, production is affected through decreased fruit size and number, as well as early senescence. Both tomato-infecting criniviruses are transmitted by the GHWF. However, ToCV is unique in that it is also transmitted by the banded wing whitefly ( $T$. abutilonea Haldeman) and B. tabaci biotypes $A$ and B. Both viruses have now been found in widespread areas of North America and Europe in both field and greenhouse environments, and are being increasingly identified in other subtropical as well as temperate areas of the world where vectors are present. TICV is abundant in tomato production fields along the west coast of North America, both in Mexico and California. ToCV is common in the southeastern United States and also has been found in Puerto Rico (31). TICV was first identified in 1993 in Orange County, CA, where growers lost $\$ 2$ million as a result of TICV infection in that year alone (33). Fields in southern California continue to experience high levels of TICV infection annually, and greenhouse producers have experienced significant economic losses from tomato criniviruses. Enclosed greenhouse production centers can lead to accumulation of high GHWF populations, which in turn facilitate viral spread throughout the facility. This is particularly a problem with organic or reduced chemical production operations, where insecticide use is either decreased or not possible.

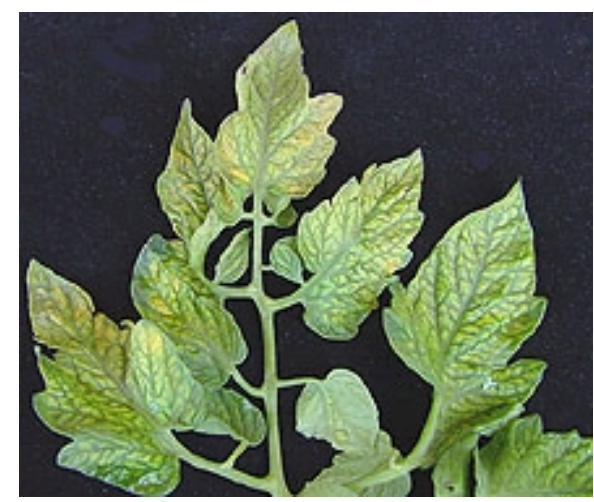

Fig. 4A. TICV symptoms on a tomato (Lycopersicon esculentum) leaf showing interveinal yellowing characteristic of TICV infection.

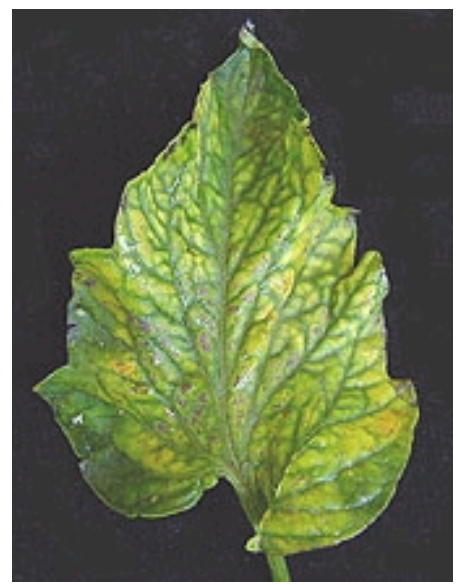

Fig. 4B. TICV symptoms on a tomato (Lycopersicon esculentum) leaflet, demonstrating both interveinal yellowing and bronzing typical of TICV infection. 


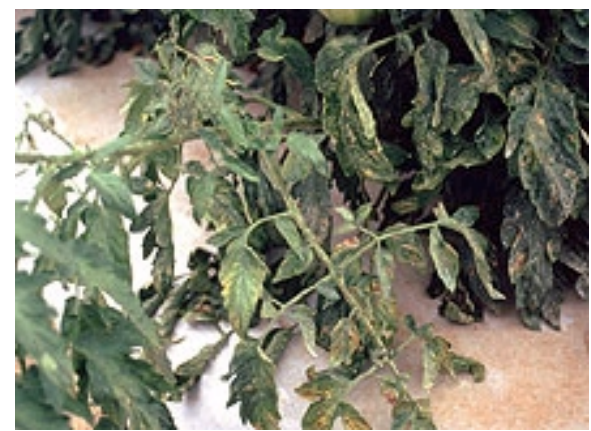

Fig. 4C. ToCV symptoms on tomato (Lycopersicon esculentum) leaves. (Photo courtesy of G. C. Wisler).

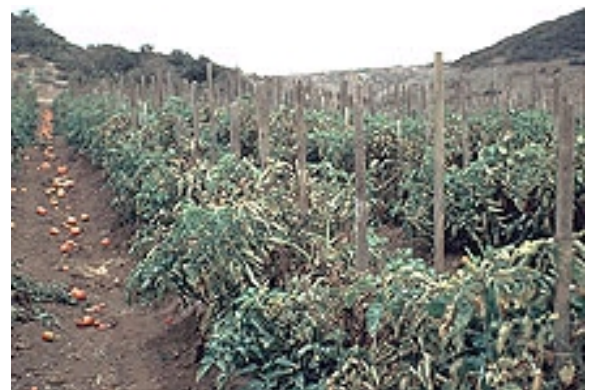

Fig. 4D. TICV symptoms in a field of severely infected tomatoes (Lycopersicon esculentum). (Photo courtesy of G. C. Wisler).

BPYV in Cucurbits. BPYV was discovered in 1965 by Duffus in California greenhouses (6), and was the first crinivirus identified. It has since been identified in greenhouses throughout the world where its only known vector, the GHWF, is often a chronic problem. BPYV has an exceptionally large host range among crop and weed species, infecting plants in at least 12 different taxonomic families $(6,16,24,26,30)$. Typical symptoms of BPYV (which vary among hosts) generally include severe yellowing, reduced fruit size and possibly early senescence in cucumber and pumpkin $(30,33)$ (Fig. 5). Symptoms begin with the appearance of chlorotic interveinal areas on leaves, expanding until most of the leaf is chlorotic, with veins remaining green. Symptomatic leaves are more brittle than asymptomatic leaves, often with a thickened feel. Greenhouse-grown cucumbers and melons are often infected with BPYV $(27,35)$, facilitated by the accumulation of the GHWF vector in the closed environment. Over the past three years pumpkin growers in California's Salinas Valley have experienced high field populations of GHWF resulting in extensive BPYV infection, leading to yellowing disease, reduced fruit size and early senescence (30). Disease incidence in pumpkin was likely exacerbated by high incidence of both BPYV and GHWF in local weed populations (Fig. 6).

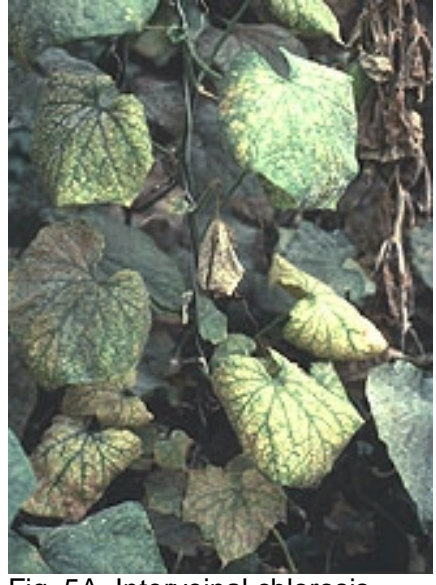

Fig. 5A. Interveinal chlorosis symptoms resulting from BPYV infection of cucumber (Cucumis sativus). (Photo courtesy of G. C. Wisler).

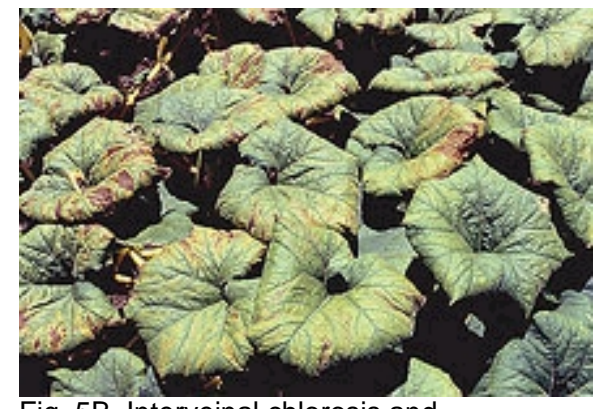

Fig. 5B. Interveinal chlorosis and subsequent necrosis resulting from BPYV infection of pumpkin (Cucurbita maxima). 


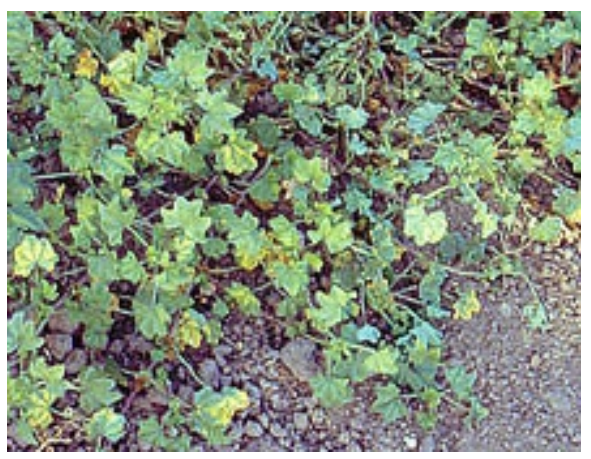

Fig. 6A. Interveinal yellowing symptoms of BPYV on the common weed, Malva parviflora.

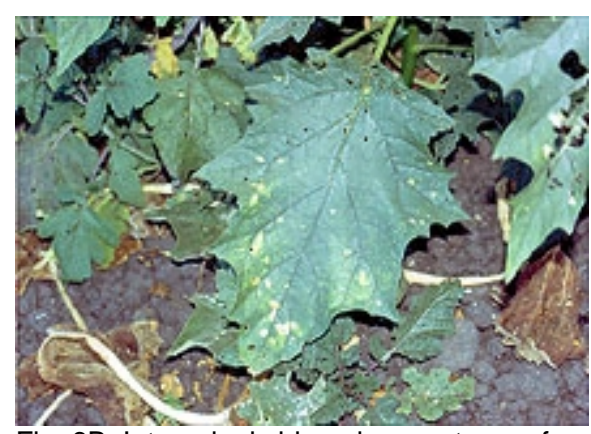

Fig. 6B. Interveinal chlorosis symptoms of BPYV on jimsonweed (Datura stramonium).

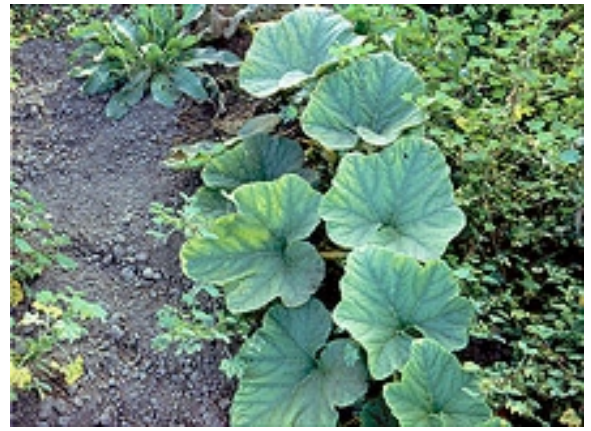

Fig. 6C. Pumpkin plant (Cucurbita maxima) surrounded by Malva parviflora, both with symptoms of BPYV infection. Susceptible weed hosts are a common source of virus inoculum in the field.

SPaV and BPYV in Strawberries. A crinivirus closely related to BPYV, Strawberry pallidosis associated virus ( $\mathrm{SPaV}$ ) is also transmitted by the GHWF (23), but appears to have a much more limited host range than BPYV. Both BPYV and SPaV are capable of causing pallidosis disease of strawberry $(24,25)$, a disease reported in numerous states and Canada $(9,10,15,24)$. Until 2003, pallidosis disease was an unrecognized problem in the American strawberry industry, although studies indicate that the disease is widespread in the eastern United States and California (15). The disease is actually the result of a virus complex including either BPYV or SPaV with any of a number of different strawberry-infecting viruses $(21,24)$. The disease causes older leaves to develop a red color, roots become stunted and plants fail to develop (Fig. 7). Fruit size and number are dramatically reduced, and the disease has been reported to reduce runners and root growth in 'Northwest' strawberry by 15 to $20 \%$ (5). During the summer of 2003 strawberries in coastal areas of California were severely damaged by pallidosis disease (24), with some fields exhibiting as high as 75 percent infection with either SPaV or BPYV, accompanied by high incidence of $\operatorname{GHWF}(23,24)$. 


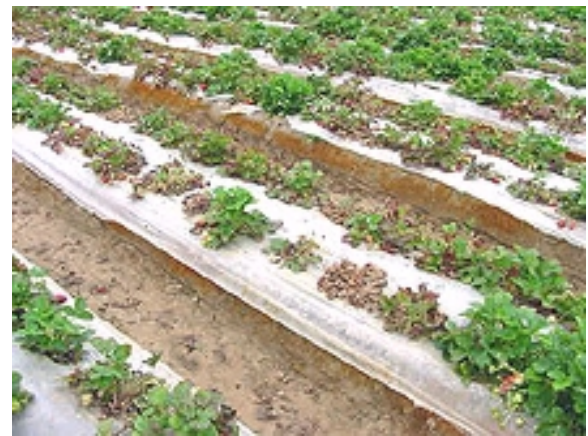

Fig. 7A. Strawberry field exhibiting stunting symptoms associated with SPaV in mixed infections with other viruses.

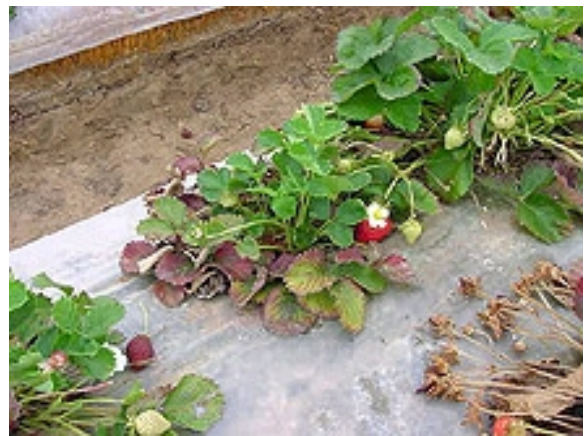

Fig. 7B. Strawberry plant with typical symptoms of stunting associated with $\mathrm{SPaV}$ in mixed infections with other strawberry viruses. Older leaves are red, with new growth appearing healthy.

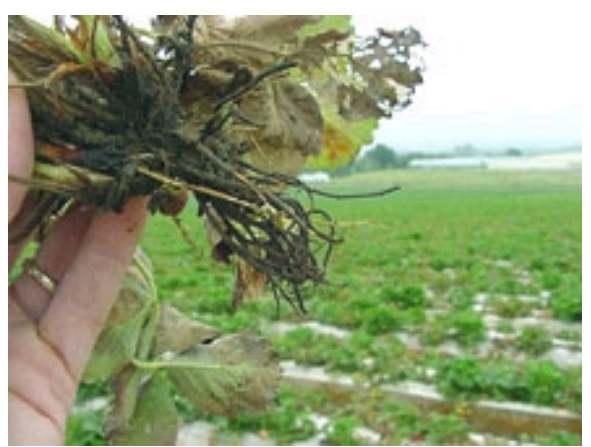

Fig. 7C. Roots of a strawberry plant that exhibits stunting due to infection by multiple viruses including SPaV. Roots are brittle and few feeder roots are visible.

\section{Confirmation of crinivirus infection}

Infection by criniviruses usually resembles symptoms of nutritional deficiencies, often resulting in misdiagnosis of virus infection as an abiotic disorder. Correlation of virus-like symptoms with prior or continuing incidence of significant whitefly populations is an excellent indicator that the symptoms may be the result of virus infection. Confirmation, however, requires testing of plant material for the presence of virus particles or viral RNA. This can be done using either serological or molecular methods. Serological methods, including enzyme-linked immunosorbant assay (ELISA) as well as Western blot can effectively identify specific criniviruses from infected leaf tissue (19). Although these methods are effective, antiserum is not always readily available, and some cross reactivity has been seen between related criniviruses (19). More reliable detection involves reverse transcriptase-polymerase chain reaction (RT-PCR). Total nucleic acid or double-stranded RNA (dsRNA) can be extracted from symptomatic leaves of plants suspected of crinivirus infection. Virus-specific primers can be obtained or designed from sequences deposited in genomic databases and from numerous publications listing information on sequence information and/or virus detection. Primers specific to sections of individual crinivirus genes can be used to selectively amplify crinivirus sequences from nucleic acid extracts of numerous and diverse plant species. RT-PCR offers the advantage of being able to screen the same sample for numerous criniviruses in a relatively short period of time. In addition to RT-PCR, molecular probes designed to match specific sections of crinivirus genomes can be used to identify and differentiate criniviruses from one another using dot blot hybridization. This technique offers the advantage of 
screening large numbers of samples simultaneously. Both RT-PCR and hybridization are highly efficient methods for detection and

differentiation of criniviruses and each offers unique advantages.

\section{Control of Criniviruses: .}

One important control measure to limit spread of criniviruses may be the identification of these viruses in nursery stock and ornamental plants. The host range of some GHWF-transmitted criniviruses is quite extensive, particularly for BPYV and to a lesser degree, TICV and ToCV. Viruses can be introduced to new areas through the distribution of susceptible ornamentals and nursery crops not suspected of harboring viruses. Due to the extensive host ranges of some of these viruses, it would be appropriate to consider testing plant material for crinivirus infection as a means of reducing accidental movement of virus. Once introduced, the viruses may become established in weed populations and moved by vectors. Some nurseries have virus indexing programs and methods for eradication of viruses through tissue culture techniques. Application of these methods to GHWFtransmitted criniviruses, coupled with effective vector control will reduce spread of these viruses, as well as limit damage to susceptible crops both in greenhouse and field environments.

The most effective form of control for any plant virus, if available, is strong stable resistance. To date there is little information on the availability of resistance to GHWF-transmitted criniviruses in any of the predominantly affected crops. Although a source of BPYV resistance has been identified in melon (12), this source has not been advanced into commercial cultivars. Similarly, no information is available on possible sources of resistance to criniviruses affecting strawberry. Ongoing research is examining wild tomato germplasm for sources of resistance to TICV, but no sources of resistance have been identified to date.

Currently, the most effective method for control of criniviruses is an effective insecticide-based control program. Imidocloprid based products are most frequently used for whitefly control, and can be applied as a foliar spray, a seed treatment or through drip application. While insecticides effectively reduce whitefly populations, such control methods are inefficient for control of viruses, since whiteflies can transmit a virus before being killed by an insecticide. In addition, most GHWF-transmitted criniviruses do not produce symptoms until 3 to 4 weeks after infection occurs. Therefore infection can be widespread by the time symptoms are observed and control measures are implemented.

\section{Organic and reduced chemical control:.}

Control of whitefly transmitted viruses in organic agriculture faces the same problem as conventional agriculture. To control the virus, one must control the whitefly vector or plant resistant varieties. The lack of available genetic resistance necessitates aggressive control measures targeting both weed hosts and the GHWF vector. A number of methods attempt to control whitefly populations in the absence of insecticide application. Two of the most widely accepted include parasitic wasps of the genera Encarsia and Eretmocerus. Encarsia formosa, in particular, has been documented as highly effective in reducing populations of GHWF and maintaining effective whitefly control over extended periods of time. It has been used successfully for whitefly control in tomato, cucumber and other greenhouse grown crops (14). The parasitic wasp kills whitefly nymphs by both direct feeding on the nymphs as well as by oviposition within the bodies of whitefly nymphs (14). Entomopathogenic fungi, including Beauveria 
bassiana and Paecilomyces fumosoroseus, are also being explored for whitefly control in both field and greenhouse settings. Studies indicate high levels of effectiveness for both fungi in reducing whitefly populations $(18,28,36)$. Other potential methods for whitefly control include the use of natural deterrents such as foliar expression of acylsugars (20), reflective mulches to repel whiteflies (22), colored mulches to lure insects away from susceptible crops (3), and insect growth regulators. Although methods of biological control can reduce overall whitefly numbers, like insecticides their ability to effectively limit virus transmission is questionable. The effectiveness of biological control methods varies based on environmental conditions, parasitoid populations in the case of insect based control, and numerous other factors. Crinivirus transmission takes only a few hours, and these viruses can be transmitted to new plants by even a small number of viruliferous whiteflies. While these methods may reduce whitefly incidence in field and greenhouse crops, and possibly slow the rate of virus transmission to some extent, they will not prevent virus transmission if infected source plants are present.

The increased incidence of criniviruses and their GHWF vector in field and greenhouse production systems highlights the need for additional efforts toward resistance and management of GHWFtransmitted viruses. Growers of susceptible crops should focus on utilizing an integrated approach to management, targeting both vector and virus. Control of whitefly vectored viruses, whether in field or greenhouse, organic or conventional agriculture is most effective when virus source plants can be eliminated. Best management will include an integrated approach focused on maintenance and use of virus free nursery material, testing of plant material exhibiting suspicious symptoms, elimination of weed and crop sources of virus to the extent possible near susceptible crops, and reducing vector populations through biological or insecticidal methods.

\section{Literature Cited}

1. Bi, J. L., Toscano, N. C., and Ballmer, G. R. 2002. Seasonal population dynamics of the greenhouse whitefly Trialeurodes vaporariorum (Homoptera: Aleyrodidae) on strawberries in Southern California. J. Econ. Entomol. 95:1179-1184.

2. Celix, A., Lopez-Sese, A., Almarza, N., Gomez-Guillamon, M. L., and Rodriguez-Cerezo, E. 1996. Characterization of Cucurbit yellow stunting disorder virus, a Bemisia tabaci-transmitted closterovirus. Phytopathology 86: 1370-1376.

3. Cohen, S. 1982. Control of whitefly vectors of viruses by color mulches. Pages 45-56 in: Pathogen, Vectors and plant diseases, approaches to control. K. F. Harris and K. Maramorosch, eds. Academic Press, NY.

4. Cohen, J., Frank, A., Vetten, H. J., Lesemann, D. E., and Loebenstein, G. 1992. Purification and properties of closeteovirus-like particles associated with a whitefly transmitted disease of sweet potato. Ann. Appl. Biol. 121:257-268.

5. Converse, R. H., and Volk, E. 1990. Some effects of pallidosis disease on strawberry growth under greenhouse conditions. Plant Disease 74:814816.

6. Duffus, J. E. 1965. Beet pseudo-yellows virus, transmitted by the greenhouse whitefly, Trialeurodes vaporariorum. Phytopathology 55: 450-453.

7. Duffus, J. E., Liu, H. -Y., and Wisler, G. C. 1996. Tomato infectious chlorosis virus-A new clostero-like virus transmitted by Trialeurodes vaporariorum. Eur. J. Plant Pathol. 102:219-226. 
8. Duffus, J. E., Liu, H. -Y., Wisler, G. C., and Li, R. H. 1996. Lettuce chlorosis virus-A new whitefly-transmitted closterovirus. Eur. J. Plant Pathol. 102:591-596.

9. Frasier, N. W., and Stubbs, L. L. 1969. Pallidosis: A new virus disease of strawberry. Plant Dis. Reptr. 53:524-526.

10. Fulton, J. P. 1987. Strawberry Pallidosis. Pages 55-56 in: Virus Diseases of Small Fruits. R .H. Converse, ed. USDA-ARS Handbook 631, Washington, D.C.

11. German-Retana, S., Candresse, T., and Martelli, G. 1999. Closteroviruses (Closteroviridae). Pages 266-273 in: Encyclopedia of Virology, 2nd ed. Academic Press, San Diego, CA.

12. Gomez-Guillamon, M. L., Tores, J. A., Soria, S., and Sese, A. I. L. 1995. Screening for resistances to Sphaerotheca fuliginea and to two yellowing diseases in Cucumis melo and related Cucumis species. Pages 205-208 in: Cucurbitaceae'94. G. Lester and J. Dunlap, eds. Gateway Printing, Edinburg, TX.

13. Harris, K. F., Pesic-Van Esbroeck, Z., and Duffus, J. E. 1996. Morphology of the sweet potato whitefly, Bemisia tabaci (Homoptera, Aleyrodidae) relative to virus transmission. Zoomorphology 116: 143156.

14. Hoddle, M. S., Van Driesche, R. G., and Sanderson, J. P. 1998. Biology and use of the whitefly parasitoid Encarsia formosa. Annu. Rev. Entomol. 43:645-669.

15. Hokanson, S., Martin, R. R., Heflebower, R. F., Jr., Rouse, R., and Maas, J. 2000. Survey of strawberry viruses occurring in commercial plantings in the state of Maryland, USA. Adv. Strawb. Res. 18:25-32.

16. Johnstone, G. R. 1987. Beet pseudo yellows closterovirus. In Plant viruses online; Descriptions and lists from the VIDE database.

17. J ones, D. R. 2003. Plant viruses transmitted by whiteflies. Euro. J. Plant Pathol. 109: 195-219.

18. Kirk, A. A., Lacey, L. A., and Goolsby, J. A. 2001. Classical biological control of Bemisia and successful integration of management strategies in the United States. Pages 309-329 in: Virus-Insect-Plant Interactions. K. F. Harris, O. P. Smith, and J. E. Duffus, eds. Academic Press. San Diego, CA.

19. Li, R. H., Wisler, G. C., Liu, H. -Y., and Duffus, J. E. 1998. Comparison of diagnostic techniques for detecting tomato infectious chlorosis virus. Plant Dis. 82:84-88.

20. Liedl, B. E., Lawson, D. M., White, K. K., Shapiro, J. A., Cohen, D. E., Carson, W. G., Trumble, J. T., and Mutschler, M. A. 1995. Acylglucoses of the wild tomato Lycopersicon pennellii alters settling and reduces oviposition of Bemisia argentifolii (Homoptera: Aleyrodidae) J. Econ. Entomol. 88: 742-748.

21. Mullin, R. H., Frasier, N. W., and Schlegel, D. E. 1975. Meristem culture of Fragaria chiloensis infected with strawberry pallidosis. Plant Dis. 59: 268.

22. Raccah, B. 1986. Nonpersistent viruses: Epidemiology and control. Pages 387-429 in: Advances in Virus Research, K. Maramorosch, F. A. Murphy, and A. J. Shatkin, eds. Academic Press, NY.

23. Tzanetakis, I. E., Halgren, A. B., Keller, K. E., Wintermantel, W. M., and Martin, R. R. 2003. Molecular characterization and epidemiology of the Strawberry pallidosis virus. Phytopathology 93: S85-S86. 
24. Tzanetakis, I. E., Wintermantel, W. M., and Martin, R. R. 2003. First report of Beet pseudo yellows virus in strawberry: A second crinivirus able to cause pallidosis disease. Plant Disease 87: 1398.

25. Tzanetakis, I. E., Halgren, A. B., Keller, K. E., Hokanson, S. C., Mc Carthy, P. L., and Martin, R. R. 2004. Identification and detection of a virus associated with Strawberry pallidosis disease. Plant Disease 88: 383-390.

26. Tzanetakis, I. E., and Martin, R. R. 2004. First report of Beet pseudo yellows virus in blackberry in the United States. Plant Disease 88: 223.

27. Van Dorst, H. J. M., Huijberts, N., and Bos., L. 1983. Yellows of glasshouse vegetables transmitted by Trialeurodes vaporariorum. Neth. J. Plant Pathol. 89: 171-184.

28. Vidal, C., Osborne, L. S., Lacey, L. A., and Fargues, J. 1998. Effect of host plant on the potential of Paecilomyces fumosoroseus (Deuteromycotina: Hyphomycetes) for controlling the silverleaf whitefly, Bemisia argentifolii (Homoptera: Aleyrodidae) in greenhouses. Biol. Control. 12:191-199.

29. Winter, S., Purac, A., Leggett, F., Frison, E. A., Rossel, H. W., and Hamilton, R. I. 1992. Partial characterization and molecular cloning of a closterovirus from sweet potato infected with the sweet potato virus disease complex from Nigeria. Phytopathology 82:869-875.

30. Wintermantel, W. M. 2004. Pumpkin (Cucurbita maxima and C. pepo), a new host of Beet pseudo yellows virus in California. Plant Disease 88: 82 .

31. Wintermantel, W. M., Polston, J. E., Escudero, J., and Paoli, E. R. 2001. First report of Tomato chlorosis virus in Puerto Rico. Plant Disease 85:228.

32. Wisler, G. C., Liu, H. J. -Y., Klaassen, V. A., Duffus, J. E., and Falk, B. W. 1996. Tomato infectious chlorosis virus has a bipartite genome and induces phloem-limited inclusions characteristic of the closteroviruses. Phytopathology 86:622-626.

33. Wisler, G. C., Duffus, J. E., Liu, H. -Y., and Li, R. H. 1998. Ecology and epidemiology of whitefly-transmitted closteroviruses. Plant Disease 82:270-280.

34. Wisler, G. C., Li, R. H., Liu, H. -Y., Lowry, D., and Duffus, J. E. 1998. Tomato chlorosis virus: A new whitefly-transmitted, phloem-limited bipartite closterovirus of tomato. Phytopathology 88:402-409.

35. Wisler, G. C., and Duffus, J. E. 2001. Transmission properties of whitefly-borne criniviruses and their impact on virus epidemiology. Pages 293-308 in: Virus-Insect-Plant Interactions. K. F. Harris, O. P. Smith, and J. E. Duffus, eds. Academic Press. San Diego, CA.

36. Wraight, S. P., Carruthers, R. I., Jaronski, S. T., Bradley, C. A., Garza, C. J., and Galaini-Wraight, S. 2000. Evaluation of the entomopathogenic fungi, Beauveria bassiana and Paecilomyces fumosoroseus, for microbial control of the silverleaf whitefly, Bemisia argentifolii. Biol. Control 17:203-217. 


\section{Electronic Resources for Further Information}

http://www.gov.on.ca/OMAFRA/english/crops/facts/03-065.htm Biology of Whiteflies In Greenhouse Crops (from Ontario Ministry of Agriculture and Food

http://www.agf. gov.bc.ca/cropprot/tomatoviruses.htm Emerging Viruses in Greenhouse Tomatoes (from British Columbia Ministry of Agriculture, Food \& Fisheries

http: //www. whitefly.org/ European Whitefly Studies Network

http://www.uckac.edu/whitefly/faqs_about_whiteflies.htm FAQs about whiteflies (from University of California, Kearney Agricultural Center

http://www. victorpest.com/articles/controlwhtfliesaphids.htm How To Control Whiteflies and Aphids (from Victor Pest Control, by National Gardening editors

http://www.nasga.org/research/03res_pallidosis.pdf Identification of strawberry pallidosis virus and development of a sensitive detection method PDF from I. E. Tzanetakis and R. R. Martin, USDA-ARS, Corvallis, Oregon

http://www.ictvdb.iacr.ac.uk/ICTVdB/index1.htm Plant viruses online: Index to ICTVdB - Virus Descriptions

http://www.eppo.org/QUARANTINE/Alert_List/viruses/tmcxxx.htm Tomato chlorosis crinivirus: A new tomato virus transmitted by whiteflies (from European and Mediterranean Plant Protection Organization

http:// www. eppo.org/QUARANTINE/Alert_List/viruses/tmicxx.htm Tomato Infectious Chlorosis Crinivirus: A new tomato virus transmitted by Trialeurodes vaporariorum (from European and Mediterranean Plant Protection Organization

http://www.ipm.ucdavis.edu/PMG/r783102911.html Tomato Infectious Chlorosis Virus (from UC IPM Online: UC Pest Management Guidelines

http://www.ipm.ucdavis.edu/PMG/r783301211.html Tomato Whiteflies (from UC IPM Online: UC Pest Management Guidelines

(C) Copyright 2004 by The American Phytopathological Society American Phytopathological Society

3340 Pilot Knob Road

St. Paul, MN 55121-2097

e-mail: aps@scisoc.org 